\title{
Thermostable HIV-1 group $O$ reverse transcriptase variants with the same fidelity as murine leukaemia virus reverse transcriptase
}

\author{
Verónica Barrioluengo, Mar Álvarez, \\ Daniela Barbieri ${ }^{1}$ and Luis Menéndez-Arias*
}

Centro de Biología Molecular "Severo Ochoa" (Consejo Superior de Investigaciones Científicas - Universidad Autónoma de Madrid), 28049 Madrid, Spain

Running title: High-fidelity HIV-1 group O RTs

${ }^{1}$ Present address: Department of Haematology and Oncological Sciences “L. e A. Serragnoli”, Microbiology Section, University of Bologna, 40138 Bologna, Italy

* To whom correspondence should be addressed. Tel.: +34 911964494; Fax: +34 911964420; E-mail: Imenendez@cbm.uam.es

Abbreviations used: MLV, murine leukaemia virus; PCR, polymerase chain reaction; RT, reverse transcriptase; WT, wild-type 


\begin{abstract}
Wild-type human immunodeficiency virus type 1 (HIV-1) group O reverse transcriptase (RT) shows increased thermostability in comparison with HIV-1 group M subtype B RT and murine leukemia virus (MLV) RT. However, its utility in the amplification of RNA targets is limited by the reduced accuracy of lentiviral RTs versus oncoretroviral RTs (i.e., MLV RT). The effects of mutations K65R, R78A and K65R/V75I on the fidelity of HIV-1 group O RTs were studied by using gel-based and M13mp2 lacZ forward mutation fidelity assays. Forward mutation assays demonstrated that mutant RTs K65R, R78A and K65R/V75I showed >9-fold increased accuracy in comparison with the wild-type enzyme, and were about two times more faithful than the MLV RT. Compared with MLV RT, all tested HIV-1 group O RT variants showed decreased frameshift fidelity. However, K65R RT showed a higher tendency to introduce one-nucleotide deletions in comparison with other HIV-1 group O RT variants. $\mathrm{R} 78 \mathrm{~A}$ had a destabilizing effect on the RT, either in the presence or absence of V75I. At temperatures above $52^{\circ} \mathrm{C}, \mathrm{K} 65 \mathrm{R}$ and $\mathrm{K} 65 \mathrm{R} / \mathrm{V} 75 \mathrm{I}$ retained similar levels of DNA polymerase activity to the wild-type HIV-1 group O RT but were more efficient than HIV-1 group $\mathrm{M}$ subtype B and MLV RTs. K65R, K65R/V75I and R78A RTs showed decreased misinsertion and mispair extension fidelity in comparison with the wild-type enzyme for most base pairs studied. These assays revealed that nucleotide selection is mainly governed by $k_{\text {pol }}$ in the case of K65R, while both $k_{\mathrm{pol}}$ and $K_{\mathrm{d}}$ affect nucleotide discrimination in the case of K65R/V75I.
\end{abstract}

Key words: HIV, reverse transcriptase, fidelity, nucleotide incorporation, DNA polymerase, mutation 


\section{INTRODUCTION}

The human immunodeficiency virus type 1 (HIV-1) reverse transcriptase (RT) is the enzyme responsible for the conversion of the viral genomic RNA into integration-competent doublestranded DNA [1]. The HIV-1 RT is a heterodimeric enzyme composed of subunits of 66 and $51 \mathrm{kDa}$, designated as p66 and p51, respectively. It shares structural homology with other DNA polymerases, including common subdomains (i.e., fingers, palm and thumb) that in p66 form the nucleic acid binding cleft. Aspartic acid residues 110, 185 and 186 define the RT DNA polymerase active site in the palm of $\mathrm{p} 66$, which also contains an RNase $\mathrm{H}$ domain located at its C-terminus [2].

Reverse transcription is error prone and contributes to the high genetic variability of HIV-1. Studies with purified HIV-1 RT have revealed an unusually high error rate while copying DNA or RNA templates (for reviews, see $[3,4]$ ). Although reported error rates for HIV-1 RT show relatively large variability, ranging from $6 \times 10^{-5}$ to $6.7 \times 10^{-4}$, it is widely assumed that oncoretroviral RTs (e.g. murine leukaemia virus (MLV) RT or avian myeloblastosis virus RT) are about 10 to 15 times more faithful than lentiviral RTs, including the HIV-1 enzyme [5,6]. HIV-1 is characterized by its remarkable variability. HIV-1 variants are classified into four major phylogenetic groups, designated as $\mathrm{M}$ (main), $\mathrm{O}$ (outlier), $\mathrm{N}$ (non$\mathrm{M} /$ non-O) and $\mathrm{P}[7,8]$. There are at least nine genetically distinct subtypes (or clades) of HIV-1 group M. These are subtypes A, B, C, D, F, G, H, J and K. Subtype B has been the dominant form in Europe, the Americas, Japan and Australia, and therefore HIV-1 group M subtype B RTs have been widely used as reference in virological and biochemical studies (e.g. RTs from clones HXB2, BH10 or NL4-3).

Mutational studies with HIV-1 RT have shown that molecular determinants of nucleotide specificity and fidelity of DNA synthesis map within the p66 subunit, mostly at or in the vicinity of the dNTP binding site (reviewed in ref. 4). Several amino acid substitutions in the HIV-1 RT (group M subtype B) have been shown to increase its intrinsic fidelity, as determined with the M13mp2 lacZ $\alpha$ forward mutation assay [9]. Examples are F61 A [10], K65R [11], L74V [11-13], V75I [14], D76V [15], R78A [16], V148I [17], Q151N [18,19], and M184I [13,20-22].

Group O HIV-1 RTs differ in about $21 \%$ of their amino acid sequence when compared with their homologous counterparts of subtype $\mathrm{B}$, and contain amino acid substitutions that confer resistance to non-nucleoside RT inhibitors [23,24]. We have recently demonstrated that a wild-type (WT) HIV-1 group O RT variant (derived from the ESP49 clone) shows increased thermal stability in comparison with MLV RT and a prototypic HIV-1 group M subtype B RT (i.e., derived from the $\mathrm{BH} 10$ strain), while showing higher efficiency in reverse transcription PCRs that included a cDNA synthesis step performed at a high temperature range $\left(57-69^{\circ} \mathrm{C}\right)$ [25]. In forward mutation assays, the WT HIV-1 group O RT showed 2.5-fold increased accuracy in comparison with the WT BH10 RT, and substituting Ile75 for Val produced a small additional increase in fidelity [25]. Now, we have studied the effects of mutations K65R and R78A on the thermostability and fidelity of DNA synthesis of HIV-1 group O RTs in the presence or absence of V75I. K65R and R78A were chosen as mutations that produced large increases in the fidelity of HIV-1 group M subtype B RTs, while retaining significant DNA polymerase activity $[11,16,26,27]$. Our results show that mutations K65R and K65R/V75I do not affect the thermal stability of the enzyme, but increase its accuracy to similar levels as the MLV RT. Mechanistic insights into the role of both mutations in the fidelity of DNA synthesis were obtained from transient kinetic assays. 


\section{EXPERIMENTAL}

\section{Mutagenesis, expression and purification of recombinant RTs}

Site-directed mutagenesis was carried out with the Quik-Change Site-Directed Mutagenesis kit (Stratagene) by following the manufacturer's instructions, and using the following mutagenic primers: 5'- CTTTGCTATAAAAAGGAAAGATAGTACTAAGTGG-3' and 5'CCACTTAGTACTATCTTTCCTTTTTATAGCAAAG-3' for K65R, 5'GCTGGTAGACTTTGCGGAATTAAACAAGAG-3' and 5'CTCTTGTTTAATTCCGCAAAGTCTACCAGC-3' for R78A, and 5'GCTGATAGACTTTGCGGAATTAAACAAGAGAAC-3' and 5'GTTCTCTTGTTTAATTCCGCAAAGTCTATCAGC-3' for the double-mutant V75I/R78A. The plasmid p66RTB $\left(\mathrm{O}_{-} \mathrm{WT}\right)$ was used as template in the mutagenesis reactions involving the specific primers for K65R, R78A and V75I/R78A [25]. The double-mutant K65R/V75I was obtained with the K65R mutagenic primers and the template p66RTB plasmid containing the DNA that encodes for the V75I mutant of HIV-1 group O RT [25]. After mutagenesis, the entire RT-coding regions were sequenced and, if correct, used for RT expression and purification.

Recombinant RTs were expressed and purified as previously described $[25,28,29]$. RTs were co-expressed with HIV-1 protease in E. coli XL1 Blue to obtain p66/p51 heterodimers, which were later purified by ionic exchange followed by affinity chromatography. Purity of the enzymes was assessed by SDS-polyacrylamide gel electrophoresis. Enzymes were quantified by active site titration before biochemical studies [30]. The MLV RT was obtained from Promega.

\section{DNA polymerase activity assays}

Assays were carried out in $50 \mathrm{mM}$ Tris- $\mathrm{HCl}$ (pH 8.0), $20 \mathrm{mM} \mathrm{NaCl}, 10 \mathrm{mM} \mathrm{MgCl} 2,8 \mathrm{mM}$ dithiothreitol, $50 \mu \mathrm{M}\left[{ }^{3} \mathrm{H}\right] \mathrm{dTTP}(6-8 \mu \mathrm{Ci} / \mathrm{ml} ; 120-160 \mathrm{Ci} / \mathrm{mol})$ (Perkin Elmer), and $1 \mu \mathrm{M}$ template-primer (poly (rA)/oligo(dT) 16 ) (concentration expressed as 3 '-hydroxyl primer termini) $[25,31]$. The thermal stability of RTs was determined by measuring the residual RNAdependent DNA polymerase activity, after preincubating $60 \mu \mathrm{l}$ of buffer containing the enzyme and the template-primer for 5 min at different temperatures in the range $37-60^{\circ} \mathrm{C}$. For RT concentrations above $25 \mathrm{nM}$, preincubating the enzymes with the homopolymeric templateprimer for up to $5 \mathrm{~min}$ at $37^{\circ} \mathrm{C}$ had a minor effect on their specific DNA polymerase activity. Polymerization reactions were initiated by adding $30 \mu \mathrm{l}$ of buffer containing $\left[{ }^{3} \mathrm{H}\right] \mathrm{dTTP}$. The final active RT concentrations in these assays were around $20 \mathrm{nM}$. At different times, aliquots $(20 \mu \mathrm{l})$ were removed into $20 \mu \mathrm{l}$ of $0.5 \mathrm{M}$ EDTA, and processed as previously described [31].

\section{Reverse transcription PCR (RT-PCR) assays}

The effect of the temperature on the efficiency of the reverse transcription reaction catalyzed by different RTs was determined by using a previously described two-step RT-PCR assay [25]. DNA amplifications were carried out with the Expand High Fidelity DNA polymerase mix (Roche). PCR primers used in these assays were: 5'-CCTAGGCACCAGGGTGTGAT-3' (ACT1), 5'-CGTACTCCTGCTTGCTGATCC-3' (ACT3), 5'CTTCAGTGAGACAGGAGCTG-3' (TUB1), and 5'-CCACAGAATCCACACCAACC-3' (TUB2). 


\section{Pre-steady-state kinetic assays}

Kinetic parameters for the incorporation of correct or incorrect nucleotides were determined as previously described $[14,25]$, using $5{ }^{\prime}-{ }^{32} \mathrm{P}$-labeled $21 \mathrm{P}\left(5^{\prime}\right.$-ATACTTTAACCATATGTATCC3') and $31 \mathrm{~T}$ (5'- TTTTTTTTTAGGATACATATGGTTAAAGTAT-3'), as primer and template, respectively. Three additional primers (21PT, 21PG and 21PA) that differ from 21P in having T, G or A (instead of C) at their 3' terminus were used in mispair extension fidelity assays. Reactions were performed under single turnover conditions in a solution containing 50$100 \mathrm{nM}$ (active sites) HIV-1 RT and a $100 \mathrm{nM}$ concentration of template-primer $31 \mathrm{~T} / 21 \mathrm{P}$, in RT buffer (50 mM Tris- $\mathrm{HCl}(\mathrm{pH} 8.0), 50 \mathrm{mM} \mathrm{KCl}, 12-24 \mathrm{mM} \mathrm{MgCl}_{2}$ ) and a variable concentration of nucleotide. Reactions involving the incorporation of incorrect nucleotides or mispair extension kinetics (i.e. incorporation of dCTP, dGTP or dATP on 31T/21P, or the extension of G:T, G:G and G:A mispairs) were conducted with excess concentration of the enzyme $(120 \mathrm{nM})$ over the template-primer duplex $(100 \mathrm{nM})$. These conditions were chosen to eliminate the influence of the enzyme turnover rate $\left(k_{\mathrm{ss}}\right)$, which interferes in the measurements of low incorporation rates.

\section{M13mp2 lacZa forward mutation assays}

Gapped duplex M13mp2 DNA was prepared as described previously [9], and used as templateprimer for DNA synthesis reactions using purified WT or mutant RTs. Gap-filling synthesis reactions were performed in a $10-\mu l$ reaction volume, containing $25 \mathrm{mM}$ Tris- $\mathrm{HCl}(\mathrm{pH} 8.0)$ buffer, $100 \mathrm{mM} \mathrm{KCl}, 2 \mathrm{mM}$ dithiothreitol, $4 \mathrm{mM} \mathrm{MgCl}$, $250 \mu \mathrm{M}$ of each dNTP (dATP, dGTP, $\mathrm{dCTP}$ and dTTP), $5 \mu \mathrm{g} / \mathrm{ml}$ gapped duplex DNA and $100 \mathrm{nM} \mathrm{RT} \mathrm{[25].} \mathrm{The} \mathrm{reactions} \mathrm{were}$ incubated at $37^{\circ} \mathrm{C}$ for $30 \mathrm{~min}$ and then stopped by adding $1 \mu \mathrm{l}$ of $60 \mathrm{mM}$ EDTA.

Polymerization products were electroporated into E. coli MC1061 host cells, and after a brief (10-min) recovery period, transformants were plated on a bacterial indicator lawn (E. coli CSH50) in M9 plates containing $0.195 \mathrm{mM}$ 5-bromo-4-chloro-3-indolyl- $\beta$-D-galactopyranoside and $0.2 \mathrm{mM}$ isopropyl-1-thio- $\beta$-D-galactopyranoside. Mutant plaques were picked, their phenotype confirmed and the phage replicative form DNA isolated for nucleotide sequencing, using primer 5'-GCTTGCTGCAACTCTCTCAG-3' (Macrogen Inc., Seoul, South Korea).

Error frequencies were calculated as previously described [9]. At least ten fill-in reactions were performed for each enzyme. The nucleotide sequence of the entire gap region was determined for all mutant plaques. Specific error rates were derived by multiplying the corrected overall error frequency with the percentage of all mutations represented by the particular class of mutations (e.g., base substitutions). This number is divided by 0.6 (the average probability of an error being expressed in the M13mp2 assay) [6], and by the total number of sites where this class of mutations can be detected (e.g., 125 for base substitutions, and 148 for frameshifts).

\section{RESULTS}

\section{Thermal stability of RTs}

The residual RNA-dependent DNA polymerase activity of WT and mutant RTs obtained after preincubating the enzymes for 5 min at different temperatures, was determined in the presence of template-primer (i.e. poly(rA)/oligo(dT) ${ }_{16}$ ). As shown in Figure 1, all tested enzymes showed similar amounts of residual activity after preincubations carried out at 42 to $48^{\circ} \mathrm{C}$. However, the MLV RT and the mutant O_R78A RT showed reduced DNA polymerase activity 
when the preincubation temperature was fixed at $50^{\circ} \mathrm{C}$. At higher temperatures $\left(e . g ., 54^{\circ} \mathrm{C}\right)$, four HIV-1 group O RT derivatives (e.g., O_WT, O_V75I, O_K65R and O_K65R/V75I) retained $25-35 \%$ of their activity at $37^{\circ} \mathrm{C}$, while the residual activities of BH10_WT and MLV RTs remained below $6 \%$ and $3 \%$, respectively. Other HIV-1 group O RT variants such as O_R78A and the double-mutant O_V75I/R78A were found to be less stable than the BH10_WT RT. These mutant enzymes showed poor nucleotide incorporation efficiency at $37^{\circ} \mathrm{C}$, and their specific activities were the lowest among all of the tested RTs (Figure 1, legend). Although the differences were relatively small, RT variants $\mathrm{O}_{-} \mathrm{WT}, \mathrm{O} \_$K65R and O_K65R/V75I seem to be slightly more stable than the O_V75I RT as demonstrated by the results obtained after preincubating the RTs and the template-primer at $56^{\circ} \mathrm{C}$.

The efficiency of reverse transcription at different temperatures was determined with a two-step RT-PCR assay including an initial cDNA synthesis reaction at a fixed temperature. The amplification of a $0.9-\mathrm{kb}$ fragment of actin from mouse liver total RNA confirmed the reduced activity of the double-mutant $\mathrm{O}_{-} \mathrm{V} 75 \mathrm{I} / \mathrm{R} 78 \mathrm{~A}$ RT in assays including a reverse transcription step at $42^{\circ} \mathrm{C}$ (Figure $2 \mathrm{~A}$ ). In addition, this mutant showed no activity when the reverse transcription reactions were carried out at temperatures above $52^{\circ} \mathrm{C}$. Both O_V75I/R78A and O_R78A RTs showed a low RT-PCR efficiency in comparison with the other HIV-1 RTs. These results were confirmed by the amplification of tubulin transcripts of $1.2 \mathrm{~kb}$ (Figure 2B). In these assays, MLV RT performed slightly better than both mutants at $57^{\circ} \mathrm{C}$. Although most of the RTs were able to produce cDNA in the presence of a small amount of RNA (typically 10 to $50 \mathrm{ng}$ ), RNA inputs as high as $1 \mu \mathrm{g}$ were required for efficient amplification of actin RNA in O_V75I/R78A RT-catalyzed reactions (Supplementary Figure S1). In contrast, WT HIV-1 group O RT and its mutants K65R and K65R/V75I retained significant activity at temperatures as high as $68^{\circ} \mathrm{C}$ in actin RNA amplifications, and also showed a better performance than the other RTs in tubulin RNA amplifications obtained after a reverse transcription step at $60^{\circ} \mathrm{C}$.

\section{Pre-steady-state kinetic analysis of thermostable HIV-1 group O RTs}

Misinsertion and mispair extension fidelity assays were used to estimate the accuracy of DNA synthesis catalyzed by HIV-1 group O RTs. The kinetic parameters ( $k_{\mathrm{pol}}$ and $\left.K_{\mathrm{d}}\right)$ for the incorporation of correct (dTTP) and incorrect nucleotides (dCTP, dGTP or dATP) are given in Table 1. For dTTP incorporation, the catalytic efficiencies $\left(k_{\mathrm{pol}} / K_{\mathrm{d}}\right)$ of studied RTs were in the range of $0.55 \mu \mathrm{M}^{-1} \cdot \mathrm{s}^{-1}$ to $1.82 \mu \mathrm{M}^{-1} \cdot \mathrm{s}^{-1}$, with O_R78A RT showing the lowest values. However, the $k_{\mathrm{pol}} / K_{\mathrm{d}}$ values for the incorporation of C, G or A by mutant O_K65R and O_K65R/V75I RTs were largely reduced.

The double-mutant K65R/V75I showed the highest misinsertion fidelities for the incorporation of A or C opposite A, although the differences with the single-mutant K65R were relatively small (Table 1; Supplementary Figure S2 A). The kinetic analysis showed that K65R produces a larger reduction of the $k_{\mathrm{pol}}$ for the incorporation of incorrect dNTPs in comparison with V75I. In comparison with the WT enzyme, the mutant O_R78A RT showed similar misinsertion fidelity for the incorporation of $\mathrm{G}$ or $\mathrm{A}$ opposite $\overline{\mathrm{A}}$, but increased efficiency of discrimination against $\mathrm{C}$ opposite $\mathrm{A}$.

The kinetics of mispair extension were determined by measuring the incorporation of a correct T opposite $\mathrm{A}$ at the $3^{\prime}$ end of the primer, using template-primer duplexes containing matched (G:C) or mismatched (G:T, G:G or G:A) termini. The results are shown in Table 2 . Mismatched extension ratios were in the range of $0.24-2.3 \times 10^{-3}$ for the G:T mispair, $0.18-$ $3.95 \times 10^{-4}$ for the G:G mispair, and lower than $2.2 \times 10^{-6}$ for the G:A mispair. By themselves, mutations K65R and V75I produce a moderate increase in mispair extension fidelity, by 
rendering enzymes with 2.8- to 5.4-fold decreased mismatched extension ratios (Table 2; Supplementary Figure S2 B). However, the double-mutant (O_K65R/V75I) showed 9.5- and 22.3-fold increases in mispair extension fidelity for G:T and G:G mismatches, respectively, suggesting an additive effect of both mutations. In the case of $\mathrm{G}: \mathrm{T}$ mismatches, the increased mispair extension fidelity of $\mathrm{O}_{-} \mathrm{K} 65 \mathrm{R} / \mathrm{V} 75 \mathrm{I} \mathrm{RT}$ can be attributed to a loss in nucleotide binding affinity $\left(K_{\mathrm{d}}\right.$ effect). However, in the case of G:G, the effects are due to the $k_{\text {pol }}$ reduction observed for the incorporation of $\mathrm{T}$ on the mismatched template-primer. Interestingly, the single-mutant O_R78A RT was also highly accurate in mispair extension assays carried out with template-primers bearing G:T or G:G mismatches. As in the case of the O_K65R/V75I RT, discrimination efficiencies for G:T and G:G mispair extensions resulted from $K_{\mathrm{d}^{-}}$and $k_{\mathrm{pol}}{ }^{-}$ effects, respectively.

\section{M13mp2 lacZa forward mutation assays}

An M13mp2-based forward mutation assay was used to analyze how amino acid substitutions in the HIV-1 group O RT could affect its intrinsic fidelity. Mutations generated when the RT copies the gapped region of the lacZ gene in $\mathrm{M} 13 \mathrm{mp} 2$ can be scored by the number of plaques with altered color phenotype (pale blue or colorless) in a specific indicator strain. Silent mutations are not detected in this assay. However, M13mp2 lacZ $\alpha$ forward mutation assays provide a fidelity assessment based on a relatively large number of mutational target sites [9]. In these assays, mutant RTs O_K65R, O_K65R/V75I and O_R78A were $>9$ times more faithful than the WT HIV-1 group O enzyme (Table 3). Moreover, their mutant frequencies were 1.5 to 2.3 times lower than those calculated for the MLV RT. Although V75I confers 1.7-fold increased fidelity when introduced in a WT HIV-1 group O RT sequence context, this amino acid substitution had no effect on the RT's accuracy when the K65R mutation was present.

The mutational specificity of HIV-1 group O RTs bearing the amino acid substitutions $\mathrm{K} 65 \mathrm{R}, \mathrm{K} 65 \mathrm{R} / \mathrm{V} 75 \mathrm{I}$ and R78A was determined after sequencing the lacZ $\alpha$ mutants generated in the forward mutation assays. Their mutational spectra (Supplementary Figures S3, S4 and S5) were compared with those obtained with WT HIV-1 group O RT and mutant V75I [25] as well as with the MLV RT (Supplementary Figure S6). Unlike in the case of O_WT RT and mutant O_V75I RT, mutations generated by O_K65R, O_K65R/V75I and O_R78̈A RTs appear to be scattered throughout the target lac $\mathrm{Z} \alpha$ sequence. A mutational hot spot located next to runs of Ts at positions -36 to -34 , and involving mostly $\mathrm{T} \rightarrow \mathrm{C}$ substitutions was observed with mutant RTs O_K65R/V75I and O_R78A. The O_K65R RT showed different mutational hot spots, located at positions $-66(\mathrm{G} \rightarrow \mathrm{T}$ substitutions), +148 (one-nucleotide deletions or $\mathrm{G} \rightarrow \mathrm{T}$ substitutions), and +151 (mostly $\mathrm{G} \rightarrow \mathrm{C}$ substitutions). Unlike in the case of the WT enzyme (O_WT RT), frameshift errors represented 15.7 to $34.3 \%$ of all errors, in the mutational spectra generated by mutants K65R, K65R/V75I and R78A (Table 4). However, MLV RT had a higher propensity to introduce frameshift mutations, and showed frameshift error rates that were 3.5 to 11 times higher than those calculated for the three mutant HIV-1 group O RTs. These enzymes showed a remarkable tendency to generate one-nucleotide deletions, which in the case of the single-mutants K65R and R78A were predominantly located at non-runs. In addition, mutant $\mathrm{O} \_$K65R RT and in a lesser extent O_R78A RT showed a stronger tendency to generate transversions instead of transitions, a property shared by the MLV RT. 


\section{DISCUSSION}

Mutational studies carried out with HIV-1 group M subtype B RTs allowed the identification of amino acid substitutions that produce significant increases in fidelity of DNA synthesis [10-22]. However, most of those amino acid changes have a negative effect on the specific DNA polymerase activity. Thus, substituting Ala for Phe61 produces an 11.7-fold increase in fidelity [10], while decreasing strand displacement DNA synthesis, processivity and template-primer binding [32,33]. On the other hand, mutant RTs with the amino acid substitutions V148I or Q151N showed 8.7- to 13.1-fold increased accuracy in comparison with the WT enzyme, although their catalytic efficiencies of dNTP incorporation were $>23$ times lower, as determined by using pre-steady-state kinetics [17,19]. Interestingly, K65R, V75I and R78A were previously identified as mutations that increased fidelity without impairing the DNA polymerase activity of $\mathrm{HIV}-1_{\mathrm{BH} 10} \mathrm{RT}[11,14,16]$. HIV $-1_{\mathrm{NL} 4-3}$ mutant frequencies were also reduced when two of those mutations (i.e., K65R and R78A) were introduced in the viral RTcoding region [34].

The interactions between the side-chain of Lys65 and the $\gamma$ phosphate of the dNTP are important for the stabilization of the incoming nucleotide in the RT active site [35] (Figure 3). K65R confers resistance to dideoxynucleotide RT inhibitors and tenofovir, and this has been related to a reduction in the insertion rate $\left(k_{\text {pol }}\right)$ of the nucleotide analogue [26,36,37; reviewed in ref. 38]. In addition, biochemical studies carried out with the HIV-1 $1_{\mathrm{HXB} 2} \mathrm{RT}$ demonstrated that K65R decreases mispair extension efficiency by reducing the catalytic rate of incorporation $\left(k_{\mathrm{pol}}\right)$ of correct dNTPs on mismatched template-primers [39]. These effects have been attributed in part to an incorrect positioning of the 3 ' end of the mispaired primer relative to the dNTP binding site [39]. Our results obtained with HIV-1 group O RTs are consistent with the previously observed $k_{\text {pol }}$-effect. However, we have also observed a significant reduction (4- to 8 -fold decrease) in nucleotide misinsertion efficiencies when the K65R substitution was present. The $k_{\text {pol }}$ reduction produced by K65R could be a consequence of the structural constraint imposed on Arg72, a residue that interacts with the $\beta$ phosphate of the incoming dNTP, due to the formation of a stacking interaction between the guanidinium planes of Arg65 and Arg72 [40]. K65R exerts similar effects on the accuracy of HIV-1 group M subtype B and group O RTs, as determined in forward mutation assays [11]. Furthermore, with both types of $\mathrm{RTs}$, the K65R mutation produces a higher ratio of transversions versus transitions and significant alterations in the mutational spectra. However, the K65R mutant displays increased frameshift fidelity over the WT HIV $-1_{\mathrm{HXB} 2} \mathrm{RT}$, with a strong propensity to introduce deletions at nucleotide runs [11]. In contrast, the O_K65R RT shows a higher proportion of frameshift errors compared with the WT enzyme and a marked tendency to generate one-nucleotide deletions at non-runs.

Val75 and Arg78 are located at the base of the $\beta 3-\beta 4$ hairpin loop (residues 56-77), a site containing several residues involved in interactions with the incoming $\mathrm{dNTP}$, that are important for drug resistance and fidelity of DNA synthesis [35; reviewed in ref. 38]. Both amino acids in the 66-kDa subunit of HIV-1 RT interact with the template nucleotide at position +1 (Figure 3). We have previously demonstrated that V75I produces a relatively modest increase in fidelity when introduced in HIV-1 RTs of groups M and O [14,25]. The mutational spectrum of the O_V75I RT was similar to that obtained with the WT enzyme [25]. Available evidence indicates that when introduced in $\mathrm{HIV}-1_{\mathrm{BH} 10} \mathrm{RT}, \mathrm{R} 78 \mathrm{~A}$ produces a large increase of fidelity as determined in forward mutation assays [16], but no information related to its mutational spectrum has been reported. Interestingly, the mutational spectrum of O_R78A RT shared with those of WT and mutant O_V75I RTs similar hot spot distributions (including a major hot spot at positions -34 to -36 ), very similar ratios of transitions versus transversions, and very low frameshift error rates. The types and frequencies of mutations generated by the 
O_R78A RT were different from those obtained with the O_K65R RT that also showed a higher frameshift error rate than the O_R78A, O_V75I and WT RTs. The high fidelity of O_R78A RT is further confirmed by the results of our kinetic assays. This enzyme appears to be very inefficient in misincorporating $C$ opposite A, as well as in extending G:T and G:G mispairs. Significant differences in the misincorporation ratios of A opposite A and G:T and G:A mispair extension efficiencies were found between O_K65R and O_R78A RTs. These results could justify in part the different mutational spectra obtained with both enzymes.

Substituting Ala for Arg78 has a destabilizing effect on the RT. The large effects on thermal stability observed with mutants R78A and V75I/R78A could be the result of the loss of interactions (mostly, hydrogen bonds) between the side chains of Arg78 and Asp76 that could affect the stability of the RT subunits. The specific RNA-dependent DNA polymerase activity at $37^{\circ} \mathrm{C}$ of the double-mutant $\left(\mathrm{O}_{-} \mathrm{V} 75 \mathrm{I} / \mathrm{R} 78 \mathrm{~A} \mathrm{RT}\right)$ was about 3 times lower than the activity shown the WT enzyme. Both O_R78A and O_V75I/R78A showed largely reduced efficiency in RT-PCR reactions carried out at temperatures above $52^{\circ} \mathrm{C}$, limiting their further development as high-fidelity thermostable RTs. V75I produced a small but detectable reduction in reverse transcription efficiency at high temperatures [25], when K65R was present, these effects were almost undetectable.

Mutants K65R and K65R/V75I showed similar accuracy in M13mp2 lacZa forward mutation assays. However, the observed mutational spectra were different. O_K65R RT showed a stronger tendency to generate frameshifts and produced more transversions than transitions. However, error specificities changed when V75I was present. Thus, the doublemutant showed a mutational spectrum with the hot spots at positions -34 to -36 and +87 found with O_V75I RT [25], but absent from the mutational spectrum of O_K65R RT. In addition, the double mutant showed a stronger tendency to generate one-nucleotide deletions at nucleotide runs, in comparison with the $\mathrm{O}$ K65R RT. These results argue in favour of a functional interaction (or epistatic effect) between K65R and V75I, and against a dominant effect of any of both mutations.

Further evidence of this interaction has been obtained from gel-based fidelity assays. Previous kinetic studies showed that O_V75I RT increases both misinsertion and mispair extension fidelity $[14,25]$. Unlike in the case of O_K65R RT, nucleotide affinity loss (i.e., increased $K_{\mathrm{d}}$ for nucleotide incorporation on mismatched template-primers) had a significant effect on the reduced mispair extension efficiencies of O_V75I RT. The double mutant K65R/V75I showed increased mispair extension fidelity for G:T and G:G mismatches, in comparison with the single mutants K65R and V75I. The increased accuracy of the double mutant was largely dominated by a $K_{\mathrm{d}}$ effect in the case of G:T mispair extension, while in the case of G:G mispairs both $k_{\mathrm{pol}}$ and $K_{\mathrm{d}}$ values were affected by the presence of K65R together with V75I. Interestingly, these effects on G:T and G:G mispair extension were also observed with the R78A mutant. Interactions between the tip of the $\beta 3-\beta 4$ hairpin loop (including Lys65) and the dNTP could be largely affected by removal of the side-chain of Arg78 that could have a strong influence on the conformation of the $\beta 3-\beta 4$ hairpin loop and its interactions with template nucleotide at position +1 .

In summary, we provide evidence that demonstrates that the fidelity of lentiviral RTs (i.e., HIV-1 RT) can be improved to the levels shown by the more faithful murine leukaemia virus RT, without altering the stability or the specific DNA polymerase activity of the enzyme. O_K65R, O_K65R/V75I and O_R78A RTs showed $>10$-fold increased accuracy for base substitutions in comparison with the WT enzyme. Base substitution error rates were similar to those obtained with MLV RT. However, the MLV RT showed a higher error rate for frameshifts (e.g., $>3$ times higher than for K65R) and a stronger tendency to produce 
transversions versus transitions in forward mutation assays. Overall error rates for MLV RT are also in good agreement with previous estimates obtained with the M13mp2 lacZ $\alpha$ forward mutation assay [5,6]. However, pre-steady-state kinetics analyses of fidelity using MLV RT were limited by its low catalytic efficiency in comparison with HIV-1 RTs [41; data not shown], as well as by the requirement of high concentrations of enzyme. The higher fidelity of the MLV RT in comparison with HIV-1 RT has been previously shown in gel-based assays using synthetic heteropolymeric template-primers [41-44]. Most of those studies have been carried out under steady-state conditions. Reported misinsertion and mispair extension ratios for MLV RT were about 2 to 8 times lower than those obtained with HIV-1 RT [42-44]. However, results were strongly dependent on the sequence and the template-primer used. Therefore, in this scenario, forward mutation assays provide a more reliable estimate of fidelity differences between both enzymes.

Although the role of K65R in the acquisition of drug resistance in HIV-1 group O RT has not been studied in detail in the clinical setting, a recent report estimates that about $10 \%$ of the HIV-1 (group M subtype B) clinical isolates bearing the K65R mutation also contain V75I [45]. It remains to be determined whether the RTs found in vivo display high fidelity and if this property has any impact on viral evolution. In any case, the RTs described in this work combine increased efficiency of reverse transcription at high temperatures with high fidelity, and should be of great utility in the amplification of RNA targets.

\section{ACKNOWLEDGMENTS}

We thank Dr. Thomas Kunkel for helpful advice.

\section{FUNDING}

This work was supported by grants of the Ministery of Science and Innovation of Spain (BIO2007/60319 and BIO2010/15542), Fundación para la Investigación y Prevención del SIDA en España (FIPSE) (grant 36771/08), Fondo de Investigación Sanitaria (through the "Red Temática de Investigación Cooperativa en SIDA" RD06/006), and an institutional grant from the Fundación Ramón Areces.

\section{REFERENCES}

1. Herschhorn, A. and Hizi, A. (2010) Retroviral reverse transcriptases. Cell. Mol. Life Sci., $67,2717-2747$

2. Sarafianos, S. G., Marchand, B., Das, K., Himmel, D. M., Parniak, M. A., Hughes, S. H. and Arnold, E. (2009) Structure and function of HIV-1 reverse transcriptase: Molecular mechanisms of polymerization and inhibition. J. Mol. Biol., 385, 693-713

3. Menéndez-Arias, L. (2002) Molecular basis of DNA synthesis and nucleotide specificity of retroviral reverse transcriptases. Prog. Nucleic Acids Res. Mol. Biol., 71, 91-147

4. Menéndez-Arias, L. (2009) Mutation rates and intrinsic fidelity of retroviral reverse transcriptases. Viruses (Basel), 1, 1137-1165

5. Roberts, J. D., Bebenek, K. and Kunkel, T. A. (1988) The accuracy of reverse transcriptase from HIV-1. Science, 242, 1171-1173. 
6. Roberts, J. D., Preston, B. D., Johnston, L. A., Soni, A., Loeb, L. A. and Kunkel, T. A. (1989) Fidelity of two retroviral reverse transcriptases during DNA-dependent DNA synthesis in vitro. Mol. Cell. Biol., 9, 469-476

7. Buonaguro, L., Tornesello, M. L. and Buonaguro, F. N. (2007) Human immunodeficiency virus type 1 subtype distribution in the worldwide epidemic: pathogenic and therapeutic implications. J. Virol., 81, 10209-10219

8. Plantier, J. C., Leoz, M., Dickerson, J. E., De Oliveira, F., Cordonnier, F., Lemée, V., Damond, F., Robertson, D. L. and Simon, F. (2009) A new human immunodeficiency virus derived from gorillas. Nat. Med., 15, 871-872

9. Bebenek, K. and Kunkel, T. A. (1995) Analyzing fidelity of DNA polymerases. Methods Enzymol., 262, 217-232

10. Fisher, T. S. and Prasad, V. R. (2002) Substitutions of $\mathrm{Phe}^{61}$ located in the vicinity of template 5'-overhang influence polymerase fidelity and nucleoside analog sensitivity of HIV-1 reverse transcriptase. J. Biol. Chem., 277, 22345-22352

11. Shah, F. S., Curr, K. A., Hamburgh, M. E., Parniak, M., Mitsuya, H., Arnez, J. G. and Prasad, V. R. (2000) Differential influence of nucleoside analog-resistance mutations K65R and L74V on the overall mutation rate and error specificity of human immunodeficiency virus type 1 reverse transcriptase. J. Biol. Chem., 275, 27037-27044

12. Rubinek, T., Bakhanashvili, M., Taube, R., Avidan, O. and Hizi, A. (1997) The fidelity of 3' misinsertion and mispair extension during DNA synthesis exhibited by two drugresistant mutants of the reverse transcriptase of human immunodeficiency virus type 1 with Leu74 $\rightarrow$ Val and Glu89 $\rightarrow$ Gly. Eur. J. Biochem., 247, 238-247

13. Jonckheere, H., De Clercq, E. and Anné, J. (2000) Fidelity analysis of HIV-1 reverse transcriptase mutants with an altered amino-acid sequence at residues Leu74, Glu89, Tyr115, Tyr183 and Met184. Eur. J. Biochem., 267, 2658-2665

14. Matamoros, T., Kim, B. and Menéndez-Arias, L. (2008) Mechanistic insights into the role of Val75 of HIV-1 reverse transcriptase in misinsertion and mispair extension fidelity of DNA synthesis. J. Mol. Biol., 375, 1234-1248

15. Kim, B., Hathaway, T. R. and Loeb, L. A. (1998) Fidelity of mutant HIV-1 reverse transcriptases: interaction with the single-stranded template influences the accuracy of DNA synthesis. Biochemistry, 37, 5831-5839

16. Kim, B., Ayran, J. C., Sagar, S. G., Adman, E. T., Fuller, S. M., Tran, N. H. and Horrigan, J. (1999) New human immunodeficiency virus type 1 reverse transcriptase (HIV-1 RT) mutants with increased fidelity of DNA synthesis. J. Biol. Chem., 274, 27666-27673

17. Weiss, K. K., Chen, R., Skasko, M., Reynolds, H. M., Lee, K., Bambara, R. A., Mansky, L. M. and Kim, B. (2004) A role for dNTP binding of human immunodeficiency virus type 1 reverse transcriptase in viral mutagenesis. Biochemistry, 43, 4490-4500

18. Weiss, K. K., Isaacs, S. J., Tran, N. H., Adman, E. T. and Kim, B. (2000) Molecular architecture of the mutagenic active site of human immunodeficiency virus type 1 reverse transcriptase: roles of the $\beta 8-\alpha \mathrm{E}$ loop in fidelity, processivity, and substrate interactions. Biochemistry, 39, 10684-10694

19. Weiss, K. K., Bambara, R. A., Kim, B. (2002) Mechanistic role of residue Gln ${ }^{151}$ in error prone DNA synthesis by human immunodeficiency virus type 1 (HIV-1) reverse transcriptase (RT). Pre-steady state kinetic study of the Q151N HIV-1 RT mutant with increased fidelity. J. Biol. Chem., 277, 22662-22669 
20. Hsu, M., Inouye, P., Rezende, L., Richard, N., Li, Z., Prasad, V. R. and Wainberg, M. A. (1997) Higher fidelity of RNA-dependent DNA mispair extension by M184V drugresistant than wild-type reverse transcriptase of human immunodeficiency virus type 1 . Nucleic Acids Res., 25, 4532-4536

21. Oude Essink, B. B., Back, N. K. T. and Berkhout, B. (1997) Increased polymerase fidelity of the 3TC-resistant variants of HIV-1 reverse transcriptase. Nucleic Acids Res., 25, 3212-3217

22. Rezende, L. F., Drosopoulos, W. C. and Prasad, V. R. (1998) The influence of 3TC resistance mutation M184I on the fidelity and error specificity of human immunodeficiency virus type 1 reverse transcriptase. Nucleic Acids Res., 26, 3066-3072

23. Quiñones-Mateu, M. E., Soriano, V., Domingo, E. and Menéndez-Arias, L. (1997) Characterization of the reverse transcriptase of a human immunodeficiency virus type 1 group O isolate. Virology, 236, 364-373

24. Menéndez-Arias, L., Abraha, A., Quiñones-Mateu, M. E., Mas, A., Camarasa, M.-J. and Arts, E. J. (2001) Functional characterization of chimeric reverse transcriptases with polypeptide subunits of highly divergent HIV-1 group $\mathrm{M}$ and $\mathrm{O}$ strains. J. Biol. Chem., 276, 27470-27479

25. Álvarez, M., Matamoros, T. and Menéndez-Arias, L. (2009) Increased thermostability and fidelity of DNA synthesis of wild-type and mutant HIV-1 group O reverse transcriptases. J. Mol. Biol., 392, 872-884

26. Sluis-Cremer, N., Arion, D., Kaushik, N., Lim, H. and Parniak, M. A. (2000) Mutational analysis of Lys $^{65}$ of HIV-1 reverse transcriptase. Biochem. J., 348, 77-82

27. Garforth, S. J., Kim, T. W., Parniak, M. A., Kool, E. T. and Prasad, V. R. (2007) Sitedirected mutagenesis in the fingers subdomain of HIV-1 reverse transcriptase reveals a specific role for the $\beta 3-\beta 4$ hairpin loop in dNTP selection. J. Mol. Biol., 365, 38-49

28. Boretto, J., Longhi, S., Navarro, J.-M., Selmi, B., Sire, J. and Canard, B. (2001) An integrated system to study multiply substituted human immunodeficiency virus type 1 reverse transcriptase. Anal. Biochem., 292, 139-147

29. Matamoros, T., Deval, J., Guerreiro, C., Mulard, L., Canard, B. and Menéndez-Arias, L. (2005) Suppression of multidrug-resistant HIV-1 reverse transcriptase primer unblocking activity by $\alpha$-phosphate-modified thymidine analogues. J. Mol. Biol., 349, 451-463

30. Kati, W. M., Johnson, K. A., Jerva, L. F. and Anderson, K. S. (1992) Mechanism and fidelity of HIV reyerse transcriptase. J. Biol. Chem., 267, 25988-25997

31. Martín-Hernández, A. M., Gutiérrez-Rivas, M., Domingo, E. and Menéndez-Arias, L. (1997) Mispair extension fidelity of human immunodeficiency virus type 1 reverse transcriptases with amino acid substitutions affecting Tyr115. Nucleic Acids Res., 25, $1383-1389$

32. Mandal, D., Dash, C., Le Grice, S. F. J. and Prasad, V. R. (2006) Analysis of HIV-1 replication block due to substitutions at F61 residue of reverse transcriptase reveals additional defects involving the RNase $\mathrm{H}$ function. Nucleic Acids Res., 34, 2853-2863

33. Agopian, A., Depollier, J., Lionne, C. and Divita, G. (2007) p66 Trp24 and Phe61 are essential for accurate association of HIV-1 reverse transcriptase with primer/template. J. Mol. Biol., 373, 127-140 
34. Mansky, L. M., Le Rouzic, E., Benichou, S. and Gajary, L. C. (2003) Influence of reverse transcriptase variants, drugs, and Vpr on human immunodeficiency virus type 1 mutant frequencies. J. Virol., 77, 2071-2080

35. Huang, H., Chopra, R., Verdine, G. L. and Harrison, S. C. (1998) Structure of a covalently trapped catalytic complex of HIV-1 reverse transcriptase: implications for drug resistance. Science, 282, 1669-1675

36. Deval, J., Navarro, J.-M., Selmi, B., Courcambeck, J., Boretto, J., Halfon, P., GarridoUrbani, S., Sire, J. and Canard, B. (2004) A loss of viral replicative capacity correlates with altered DNA polymerization kinetics by the human immunodeficiency virus reverse transcriptase bearing the K65R and L74V dideoxynucleoside resistance substitutions. J. Biol. Chem., 279, 25489-25496

37. Sluis-Cremer, N., Sheen, C.-W., Zelina, S., Torres, P. S. A., Parikh, U. M. and Mellors, J. W. (2007) Molecular mechanism by which the K70E mutation in human immunodeficiency virus type 1 reverse transcriptase confers resistance to nucleoside reverse transcriptase inhibitors. Antimicrob. Agents Chemother., 51, 48-53

38. Menéndez-Arias, L. (2008) Mechanisms of resistance to nucleoside analogue inhibitors of HIV-1 reverse transcriptase. Virus Res., 134, 124-146

39. Garforth, S. J., Domaoal, R. A., Lwatula, C., Landau, M. J., Meyer, A. J., Anderson, K. S. and Prasad, V. R. (2010) K65R and K65A substitutions in HIV-1 reverse transcriptase enhance polymerase fidelity by decreasing both dNTP misinsertion and mispaired primer extension efficiencies. J. Mol. Biol., 401, 33-44

40. Das, K., Bandwar, R. P., White, K. L., Feng, J. Y., Sarafianos, S. G., Tuske, S., Tu, X., Clark, A. D. Jr., Boyer, P. L., Hou, X., Gaffney, B. L., Jones, R. A., Miller, M. D., Hughes, S. H. and Arnold, E. (2009) Structural basis for the role of the K65R mutation in HIV-1 reverse transcriptase polymerization, excision antagonism, and tenofovir resistance. J. Biol. Chem., 284, 35092-35100

41. Skasko, M., Weiss, K. K., Reynolds, H. M., Jamburuthugoda, V., Lee, K. and Kim, B. (2005) Mechanistic differences in RNA-dependent DNA polymerization and fidelity between murine leukemia virus and HIV-1 reverse transcriptases. J. Biol. Chem., 280, $12190-12200$

42. Ricchetti, M. and Buc, H. (1990) Reverse transcriptases and genomic variability: the accuracy of DNA replication is enzyme specific and sequence dependent. EMBO J., 9, $1583-1593$

43. Bakhanashvili, M. and Hizi, A. (1992) Fidelity of the RNA-dependent DNA synthesis exhibited by the reverse transcriptases of human immunodeficiency virus types 1 and 2 and of murine leukemia virus: Mispair extension frequencies. Biochemistry, 31, 93939398

44. Bakhanashvili, M. and Hizi, A. (1993) The fidelity of the reverse transcriptases of human immunodeficiency viruses and murine leukemia virus, exhibited by the mispair extension frequencies, is sequence dependent and enzyme related. FEBS Lett., 319, 201-205

45. McColl, D. J., Chappey, C., Parkin, N. T. and Miller, M. D. (2008) Prevalence, genotypic associations and phenotypic characterization of K65R, L74V and other HIV-1 RT resistance mutations in a commercial database. Antivir. Ther., 13, 189-197 


\section{LEGEND TO FIGURES}

\section{Figure 1. Thermal stability of RTs.}

RNA-dependent DNA polymerization reactions were carried out at $37^{\circ} \mathrm{C}$ in the presence of 1 $\mu \mathrm{M}$ poly(rA)/oligo(dT) $)_{16}$ and $50 \mu \mathrm{M}\left[{ }^{3} \mathrm{H}\right] \mathrm{dTTP}$. The active RT concentration in the assay was 15-20 nM. Relative dTTP incorporation rates were measured after preincubating the enzymes with the template/primer for $5 \mathrm{~min}$ at the indicated temperatures. For each enzyme, percent activity was normalized relative to the value obtained after preincubating the RTs at $37^{\circ} \mathrm{C}$ $(100 \%)$. Reported values for each enzyme were obtained from at least four independent experiments. The nucleotide incorporation rates obtained after preincubating the enzymes at $37^{\circ} \mathrm{C}$ were $0.72 \pm 0.28 \mathrm{~s}^{-1}$ for O_WT RT, $0.92 \pm 0.25 \mathrm{~s}^{-1}$ for O_K65R RT, $0.61 \pm 0.26 \mathrm{~s}^{-1}$ for O_K65R/V75I RT, $0.45 \pm 0.06 \mathrm{~s}^{-1}$ for OR78A RT, $0.25 \pm 0.06 \mathrm{~s}^{-1}$ for O V75I/R78A RT, 0.57 $\pm \overline{0} .06 \mathrm{~s}^{-1}$ for O_V75I RT, $1.17 \pm 0.4 \mathrm{~s}^{-1}$ for BH10_WT RT, and $1.16 \pm 0 . \overline{4} \mathrm{~s}^{-1}$ for MLV RT.

\section{Figure 2. Effect of temperature on cDNA synthesis and two-step RT-PCR.}

The cDNA synthesis reactions were carried out for $60 \mathrm{~min}$ at the indicated temperatures, in a buffer containing $50 \mathrm{ng} / \mu 1$ of mouse liver RNA and $150 \mathrm{nM} \mathrm{RT} \mathrm{(active} \mathrm{site} \mathrm{concentration).}$ Reactions were stopped by heating at $92^{\circ} \mathrm{C}$ for $10 \mathrm{~min}$. Two microliters of the cDNA synthesis reaction and 1.75 units of Expand High Fidelity DNA polymerase mix were used in all amplifications. Panel A shows amplifications of a $0.9-\mathrm{Kb}$ fragment of actin DNA, obtained with primers ACT1 and ACT3. Panel B shows amplifications of a 1.2-Kb fragment of tubulin DNA, obtained with primers TUB1 and TUB2. Lanes 1 and $\mathrm{C}$ show molecular weight markers (HindIII digest of phage $\Phi 29$ DNA), and a control reaction (carried out in the absence of RT), respectively. Lanes 2 to 9 show the result of two-step RT-PCRs that included a cDNA synthesis step, carried out with O_K65R RT (lane 2), O_K65R/V75I RT (lane 3), O_R78A RT (lane 4), O_V75I/R78A RT (lane 5), O_WT RT (lane 6), O_V75I RT (lane 7), BH10_WT RT (lane 8) and MLV RT (lane 9). Data are representative of three independent experiments.

Figure 3. Crystal structures of the ternary complex of HIV-1 RT bound to doublestranded DNA (dsDNA) and dTTP showing the location of Lys65, Val75 and Arg78 in the 66-kDa subunit of the enzyme.

(A) Ternary complex of HIV-1 [group M subtype B (isolate HXB2)] RT, dsDNA and dTTP (PDB file 1RTD) [35]. The RT subunits p66 and p51 are represented by cyan and green ribbons, respectively. The template and primer strands are represented with grey and white sphere models. The incoming dNTP is shown in yellow. The side chains of Lys65, Val75 and Arg78 are shown in blue, magenta and orange, respectively. Panel (B) shows the $\beta 3-\beta 4$ hairpin loop and the dNTP binding site with the location of relevant residues. 
Table 1. Pre-steady-state kinetic parameters for misincorporation

\begin{tabular}{|l|c|c|c|c|c|}
\hline Enzyme & Nucleotide & $\begin{array}{c}k_{\text {pol }} \\
\left(\mathrm{s}^{-1}\right)\end{array}$ & $\begin{array}{c}K_{\mathrm{d}} \\
(\mu \mathrm{M})\end{array}$ & $\begin{array}{c}k_{\text {pol }} / K_{\mathrm{d}} \\
\left(\mu \mathrm{M}^{-1} \cdot \mathrm{s}^{-1}\right)\end{array}$ & $\begin{array}{c}\text { Misinsertion } \\
\text { ratio }\left(f_{\text {ins }}\right)\end{array}$ \\
\hline \multirow{5}{*}{ O_WT RT b } & dTTP & $14.7 \pm 1.0$ & $11.8 \pm 2.9$ & $1.25 \pm 0.32$ & \\
\cline { 2 - 6 } & dCTP & $0.72 \pm 0.10$ & $7652 \pm 2083$ & $(9.5 \pm 2.9) \times 10^{-5}$ & $7.57 \times 10^{-5}$ \\
\cline { 2 - 6 } & dGTP & $0.15 \pm 0.03$ & $11730 \pm 3750$ & $(1.3 \pm 0.5) \times 10^{-5}$ & $1.03 \times 10^{-5}$ \\
\cline { 2 - 6 } & dATP & $(7.3 \pm 0.2) \times 10^{-3}$ & $1485 \pm 150$ & $(4.9 \pm 2.2) \times 10^{-6}$ & $3.94 \times 10^{-6}$ \\
\hline O_V75I RT b & dTTP & $13.9 \pm 1.2$ & $14.6 \pm 4.3$ & $0.96 \pm 0.30$ & \\
\cline { 2 - 6 } & dCTP & $0.27 \pm 0.05$ & $11023 \pm 3792$ & $(2.4 \pm 0.9) \times 10^{-5}$ & $2.54 \times 10^{-5}(3.0)$ \\
\cline { 2 - 6 } & dGTP & $(6.3 \pm 0.9) \times 10^{-2}$ & $7481 \pm 2307$ & $(8.4 \pm 2.9) \times 10^{-6}$ & $8.76 \times 10^{-6}(1.2)$ \\
\cline { 2 - 6 } & dATP & $(2.2 \pm 0.2) \times 10^{-3}$ & $2308 \pm 720$ & $(9.5 \pm 3.1) \times 10^{-7}$ & $9.98 \times 10^{-7}(3.9)$ \\
\hline O_K65R RT & dTTP & $10.7 \pm 0.9$ & $5.8 \pm 1.9$ & $1.82 \pm 0.60$ & \\
\cline { 2 - 6 } & dCTP & $0.17 \pm 0.02$ & $9559 \pm 1908$ & $(1.7 \pm 0.4) \times 10^{-5}$ & $9.51 \times 10^{-6}(8.0)$ \\
\cline { 2 - 6 } & dGTP & $(3.1 \pm 1.9) \times 10^{-2}$ & $6452 \pm 857$ & $(4.8 \pm 0.7) \times 10^{-6}$ & $2.66 \times 10^{-6}(3.9)$ \\
\cline { 2 - 6 } & dATP & $(4.8 \pm 0.1) \times 10^{-3}$ & $3680 \pm 178$ & $(1.3 \pm 0.1) \times 10^{-6}$ & $7.09 \times 10^{-7}(5.6)$ \\
\hline O_K65R/V75I RT & dTTP & $12.7 \pm 1.3$ & $13.3 \pm 3.7$ & $0.95 \pm 0.28$ & \\
\cline { 2 - 6 } & dCTP & $(3.3 \pm 0.3) \times 10^{-2}$ & $5686 \pm 995$ & $(5.8 \pm 1.1) \times 10^{-6}$ & $6.06 \times 10^{-6}(12.5)$ \\
\cline { 2 - 6 } & dGTP & $0.11 \pm 0.02$ & $13430 \pm 4605$ & $(8.3 \pm 3.3) \times 10^{-6}$ & $8.70 \times 10^{-6}(1.2)$ \\
\cline { 2 - 6 } & dATP & $(3.3 \pm 0.2) \times 10^{-3}$ & $5290 \pm 553$ & $(6.2 \pm 0.7) \times 10^{-7}$ & $6.52 \times 10^{-7}(6.0)$ \\
\hline O_R78A RT & dTTP & $9.4 \pm 1.1$ & $17.2 \pm 5.3$ & $0.55 \pm 0.18$ & \\
\cline { 2 - 6 } & dCTP & $(1.6 \pm 0.2) \times 10^{-2}$ & $6939 \pm 1740$ & $(2.4 \pm 0.7) \times 10^{-6}$ & $4.27 \times 10^{-6}(17.7)$ \\
\cline { 2 - 6 } & dGTP & $(6.2 \pm 0.4) \times 10^{-3}$ & $2313 \pm 361$ & $(2.7 \pm 0.5) \times 10^{-6}$ & $4.89 \times 10^{-6}(2.1)$ \\
\cline { 2 - 6 } & dATP & $(1.9 \pm 0.7) \times 10^{-3}$ & $1122 \pm 165$ & $(1.7 \pm 0.3) \times 10^{-6}$ & $3.13 \times 10^{-6}(1.4)$ \\
\hline
\end{tabular}

The template-primer 31T/21P was used as the substrate. Data shown are the mean values \pm standard deviation. Each of the assays was performed independently at least three times.

${ }^{\mathrm{a}} f_{\text {ins }}=\left[k_{\mathrm{pol}}(\right.$ incorrect $) / K_{\mathrm{d}}($ incorrect $\left.)\right] /\left[k_{\mathrm{pol}}(\right.$ correct $) / K_{\mathrm{d}}($ correct $\left.)\right]$, where incorrect nucleotides were dCTP, dGTP or dATP, while the correct nucleotide was dTTP. Numbers between parentheses represent the relative increase of fidelity, as determined for each incorrect nucleotide as the ratio: $f_{\text {ins }}\left(\mathrm{O}_{-} \mathrm{WT} \mathrm{RT}\right) / \mathrm{f}_{\text {ins }}$ (mutant $\mathrm{RT}$ ).

${ }^{\mathrm{b}}$ Reported values for O_WT RT and O_V75I RT were taken from ref. [25]. 
Table 2. Pre-steady-state kinetic parameters for mispair extension

\begin{tabular}{|c|c|c|c|c|c|}
\hline Enzyme & $\begin{array}{l}\text { Base pair } \\
\text { at the } 3^{\prime} \text { end }\end{array}$ & $\begin{array}{l}k_{\text {pol }} \\
\left(s^{-1}\right)\end{array}$ & $\begin{array}{c}K_{d} \\
(\mu \mathrm{M})\end{array}$ & $\begin{array}{c}K_{\text {poo }} / K_{\mathrm{d}} \\
\left(\mu \mathrm{M}^{-1} \cdot \mathrm{s}^{-1}\right)\end{array}$ & $\begin{array}{l}\text { Mismatch } \\
\text { extensión } \\
\text { ratio }\left(f_{\text {ext }}\right)\end{array}$ \\
\hline \multirow[t]{4}{*}{ O_WT RT ${ }^{c}$} & G:C & $14.7 \pm 1.0$ & $11.8 \pm 2.9$ & $1.25 \pm 0.32$ & 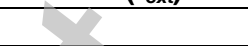 \\
\hline & G:T & $7.6 \pm 0.9$ & $2638 \pm 785$ & $(2.9 \pm 0.9) \times 10^{-3}$ & $2.30 \times 10^{-3}$ \\
\hline & G:G & $0.56 \pm 0.07$ & $1132 \pm 316$ & $(4.9 \pm 1.5) \times 10^{-4}$ & $3.95 \times 10^{-4}$ \\
\hline & G:A & $(2.1 \pm 0.3) \times 10^{-2}$ & $7817 \pm 2334$ & $(2.7 \pm 0.9) \times 10^{-6}$ & $2.17 \times 10^{-6}$ \\
\hline \multirow[t]{4}{*}{ O_V75I RT ${ }^{\mathrm{C}}$} & G:C & $13.9 \pm 1.2$ & $14.6 \pm 4.3$ & $0.96 \pm 0.30$ & \\
\hline & G:T & $2.8 \pm 0.2$ & $4400 \pm 789$ & $(6.3 \pm 1.2) \times 10^{-4}$ & $6.56 \times 10^{-4}(3.5)$ \\
\hline & G:G & $0.32 \pm 0.01$ & $2426 \pm 178$ & $(1.3 \pm 0.1) \times 10^{-4}$ & $1.39 \times 10^{-4}(2.8)$ \\
\hline & G:A & $(6.8 \pm 0.8) \times 10^{-3}$ & $12110 \pm 2536$ & $(5.6 \pm 1.3) \times 10^{-7}$ & $5.86 \times 10^{-7}(3.7)$ \\
\hline \multirow[t]{4}{*}{ O_K65R RT } & G:C & $10.7 \pm 0.9$ & $5.8 \pm 1.9$ & $1.82 \pm 0.60$ & \\
\hline & G:T & $3.1 \pm 0.5$ & $2214 \pm 1058$ & $(1.4 \pm 0.7) \times 10^{-3}$ & $7.80 \times 10^{-4}(2.9)$ \\
\hline & G:G & $0.19 \pm 0.02$ & $1416 \pm 328.4$ & $(1.3 \pm 0.3) \times 10^{-4}$ & $7.25 \times 10^{-5}(5.4)$ \\
\hline & G:A & $(1.3 \pm 0.2) \times 10^{-2}$ & $15180 \pm 4239$ & $(8.7 \pm 2.9) \times 10^{-7}$ & $4.78 \times 10^{-7}(4.5)$ \\
\hline \multirow{4}{*}{$\begin{array}{l}\text { O_K65R/V75I } \\
\text { RT }\end{array}$} & G:C & $12.7 \pm 1.3$ & $13.3 \pm 3.7$ & $0.95 \pm 0.28$ & \\
\hline & G:T & $2.4 \pm 0.2$ & $10450 \pm 1644$ & $(2.3 \pm 0.4) \times 10^{-4}$ & $2.43 \times 10^{-4}(9.5)$ \\
\hline & G:G & $(8.7 \pm 0.9) \times 10^{-2}$ & $5213 \pm 1096$ & $(1.7 \pm 0.4) \times 10^{-5}$ & $1.77 \times 10^{-5}(22.3)$ \\
\hline & G:A & $(1.4 \pm 0.1) \times 10^{-3}$ & $3578 \pm 786$ & $(3.9 \pm 0.9) \times 10^{-7}$ & $4.15 \times 10^{-7}(5.2)$ \\
\hline \multirow[t]{4}{*}{ O_R78A RT } & G:C & $9.4 \pm 1.1$ & $17.2 \pm 5.3$ & $0.55 \pm 0.18$ & \\
\hline & G:T & $1.4 \pm 0.2^{d}$ & $>8000$ & ND & ND \\
\hline & G:G & $(3.4 \pm 0.3) \times 10^{-2}$ & $2158 \pm 484$ & $(1.6 \pm 0.4) \times 10^{-5}$ & $2.87 \times 10^{-5}(13.8)$ \\
\hline & G:A & $(2.0 \pm 0.2) \times 10^{-3}$ & $2926 \pm 572$ & $(6.8 \pm 1.4) \times 10^{-7}$ & $1.24 \times 10^{-6}(1.8)$ \\
\hline
\end{tabular}

The template-primer $31 \mathrm{~T} / 21 \mathrm{P}$ was used as the substrate. Data shown are the mean values \pm standard deviation. Each of the assays was performed independently at least three times.

${ }^{a}$ The first base corresponds to the template and the second to the primer.

${ }^{\mathrm{b}} f_{\mathrm{ext}}=\left[k_{\mathrm{pol}}(\right.$ mismatched $) / K_{\mathrm{d}}($ mismatched $\left.)\right] /\left[k_{\mathrm{pol}}(\right.$ matched $) / K_{\mathrm{d}}($ matched $\left.)\right]$. Numbers between parenthesis represent the relative increase of fidelity, as determined for each mispair as the ratio: $f_{\text {ext }}\left(\mathrm{O}_{-} \mathrm{WT} \mathrm{RT}\right) / f_{\text {ext }}$ (mutant RT).

${ }^{\mathrm{c}}$ Reported values for O_WT RT and O_V75I RT were taken from ref. [25].

${ }^{\mathrm{d}}$ A linear relationship between $k_{\mathrm{obs}}$ and [dTTP] was observed at nucleotide concentrations between 0.5 and $12 \mathrm{mM}$. The reported value is the $k_{\text {obs }}$ obtained at $12 \mathrm{mM}$ dTTP. ND, not determined. 
Table 3. Accuracy of RT variants in M13mp2 lacZa forward mutation assays.

\begin{tabular}{|c|c|c|c|c|c|}
\hline \multirow[b]{2}{*}{ Enzymes } & \multirow[b]{2}{*}{ Total plaques } & \multirow{2}{*}{$\begin{array}{l}\text { Mutant } \\
\text { plaques }\end{array}$} & \multirow{2}{*}{$\begin{array}{c}\text { Mutant } \\
\text { frequency }\end{array}$} & \multicolumn{2}{|c|}{ Fidelity (fold change) } \\
\hline & & & & $\begin{array}{l}\text { (relative to } \\
\text { O_WT RT) }\end{array}$ & $\begin{array}{l}\text { (relative to } \\
\text { MLV RT) }\end{array}$ \\
\hline O_WT RT ${ }^{b}$ & 7579 & 63 & 0.00831 & 1 & 0.16 \\
\hline O_K65R RT & 75474 & 58 & 0.00077 & 10.8 & 1.8 \\
\hline O_K65R/V75I RT & 55657 & 50 & 0.00089 & 9.3 & 1.5 \\
\hline O_V75I RT ${ }^{b}$ & 9894 & 47 & 0.00475 & 1.7 & 0.28 \\
\hline O_R78A RT & 80664 & 48 & 0.00059 & 14.1 & 2.3 \\
\hline MLV RT & 29648 & 40 & 0.00135 & 6.2 & 1 \\
\hline
\end{tabular}

${ }^{a}$ Reported background frequencies in this assay (usually around $6 \times 10^{-4}$ ) [9,14] are in most cases a consequence of M13mp2 DNA rearrangements that result in the loss of the lacZ gene. In order to have a better estimate of the background due to errors introduced by $E$. coli polymerases while copying the lacZ sequence, phage DNA was obtained from all mutant plaques and the sequence of the reporter gene was determined in all cases. In control experiments involving a total of 22189 plaques, no mutations in lacZ were identified after analyzing the results obtained from 2-3 E. coli electroporations carried out with gapped M13mp2 DNA substrate.

${ }^{\mathrm{b}}$ Reported values for O_WT RT and O_V75I RT were taken from ref. [25]. 
Table 4. Summary of error rates for RTs, for various classes of mutations.

\begin{tabular}{|c|c|c|c|c|c|c|c|c|c|c|}
\hline \multirow[b]{2}{*}{ Mutation type } & \multicolumn{2}{|c|}{ O_WT RT ${ }^{\mathrm{a}}$} & \multicolumn{2}{|c|}{ O_K65R RT } & \multicolumn{2}{|c|}{ O_K65R/V75I RT } & \multicolumn{2}{|c|}{ O_R78A RT } & \multicolumn{2}{|c|}{ MLV RT } \\
\hline & $\begin{array}{l}\text { No. of } \\
\text { errors }\end{array}$ & $\begin{array}{l}\text { Error } \\
\text { rate }\end{array}$ & $\begin{array}{l}\text { No. of } \\
\text { errors }\end{array}$ & $\begin{array}{l}\text { Error } \\
\text { rate }\end{array}$ & $\begin{array}{l}\text { No. of } \\
\text { errors }\end{array}$ & $\begin{array}{l}\text { Error } \\
\text { rate }\end{array}$ & $\begin{array}{l}\text { No. of } \\
\text { errors }\end{array}$ & $\begin{array}{l}\text { Error } \\
\text { rate } \\
\end{array}$ & $\begin{array}{l}\text { No. of } \\
\text { errors }\end{array}$ & $\begin{array}{l}\text { Error } \\
\text { rate }\end{array}$ \\
\hline All classes & 49 & 1/17166 & 67 & $1 / 160185(9.3)^{b}$ & 50 & 1/158288 (9.2) & 51 & $1 / 224910(13.1)$ & 49 & $1 / 86040(5.0)$ \\
\hline Base substitutions & 49 & $1 / 9053$ & 44 & $1 / 128649$ (14.2) & 39 & $1 / 107033$ (11.8) & 43 & $1 / 140693$ (15.5) & 19 & $1 / 117032$ (12.9) \\
\hline Transitions & 25 (51\%) & & 8 (18.2\%) & & 21 (53.8\%) & & 19 (44.2\%) & & $3(15.8 \%)$ & \\
\hline Transversions & 24 (49\%) & & 36 (81.8\%) & & 18 (46.2\%) & & $24(55.8 \%)$ & & $16(84.2 \%)$ & \\
\hline Frameshifts & 0 & $<1 / 541516$ & 23 & $1 / 291395(<0.5)$ & 11 & $1 / 449304(<0.8)$ & 8 & $1 / 895370(<1.7)$ & 30 & $1 / 87758(<0.16)$ \\
\hline Insertions & 0 & & $2(8.7 \%)$ & & $1(9.1 \%)$ & & $1(12.5 \%)$ & & $8(26.7 \%)$ & \\
\hline Deletions & 0 & & $21(91.3 \%)$ & & $10(90.9 \%)$ & & 7 (87.5\%) & & $22(73.3 \%)$ & \\
\hline At runs & 0 & $<1 / 280371$ & 6 & $1 / 596245(<2.1)$ & 6 & $1 / 439690(<1.6)$ & 2 & $1 / 1911737(<6.8)$ & 14 & $1 / 100380(<0.4)$ \\
\hline At non-runs & 0 & $<1 / 244881$ & 17 & $1 / 183801(<0.7)$ & 5 & $1 / 460840(<1.9)$ & 6 & $1 / 556582(<2.3)$ & 16 & $1 / 76714(<0.3)$ \\
\hline
\end{tabular}

${ }^{\text {a }}$ Reported values for O_WT RT were taken from ref. [25].

${ }^{\mathrm{b}}$ Numbers between parentheses represent the RT's accuracy for each mutation type (given as fold-change of the error rate relative to the value obtained with O_WT RT). 


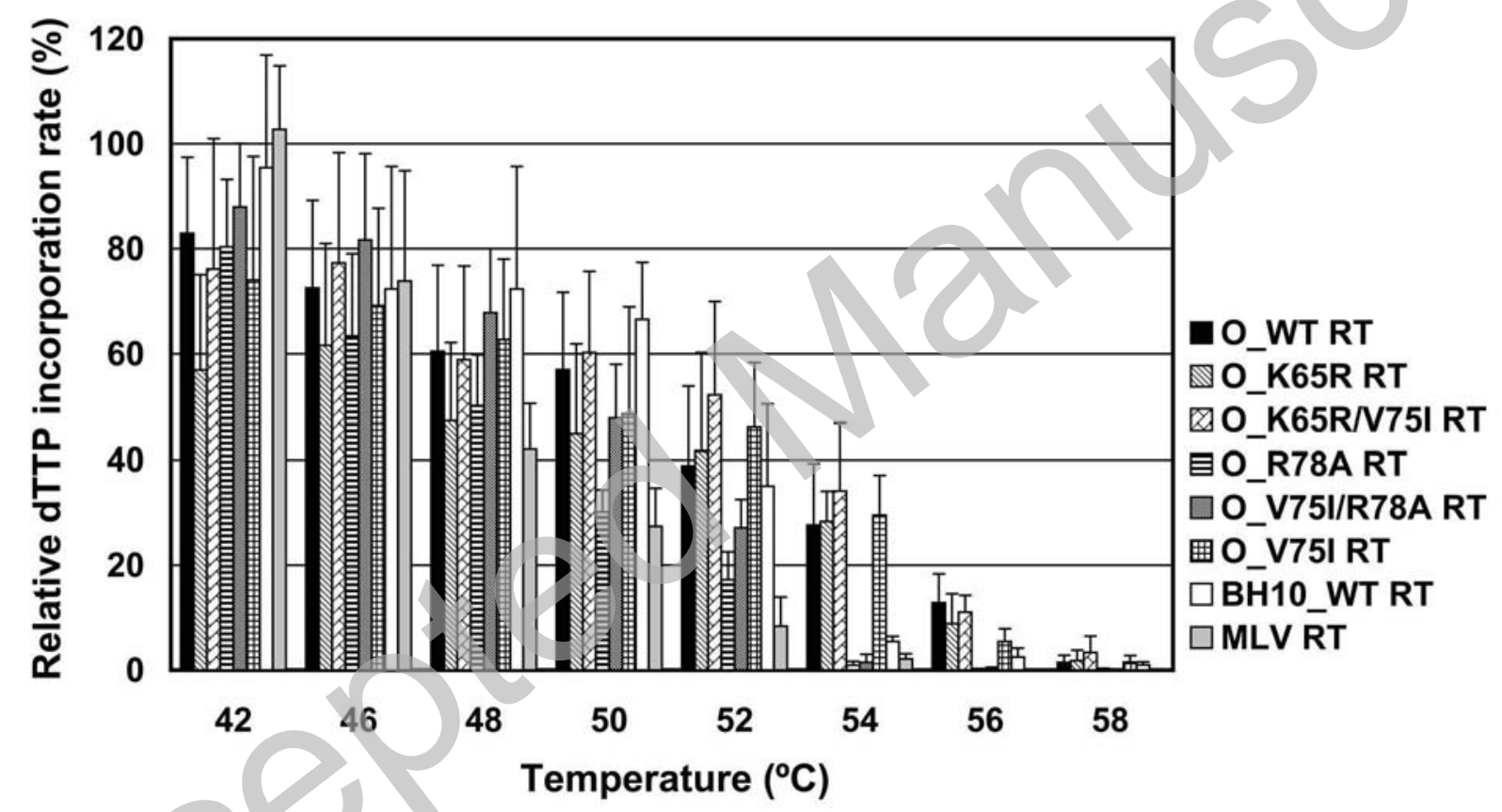



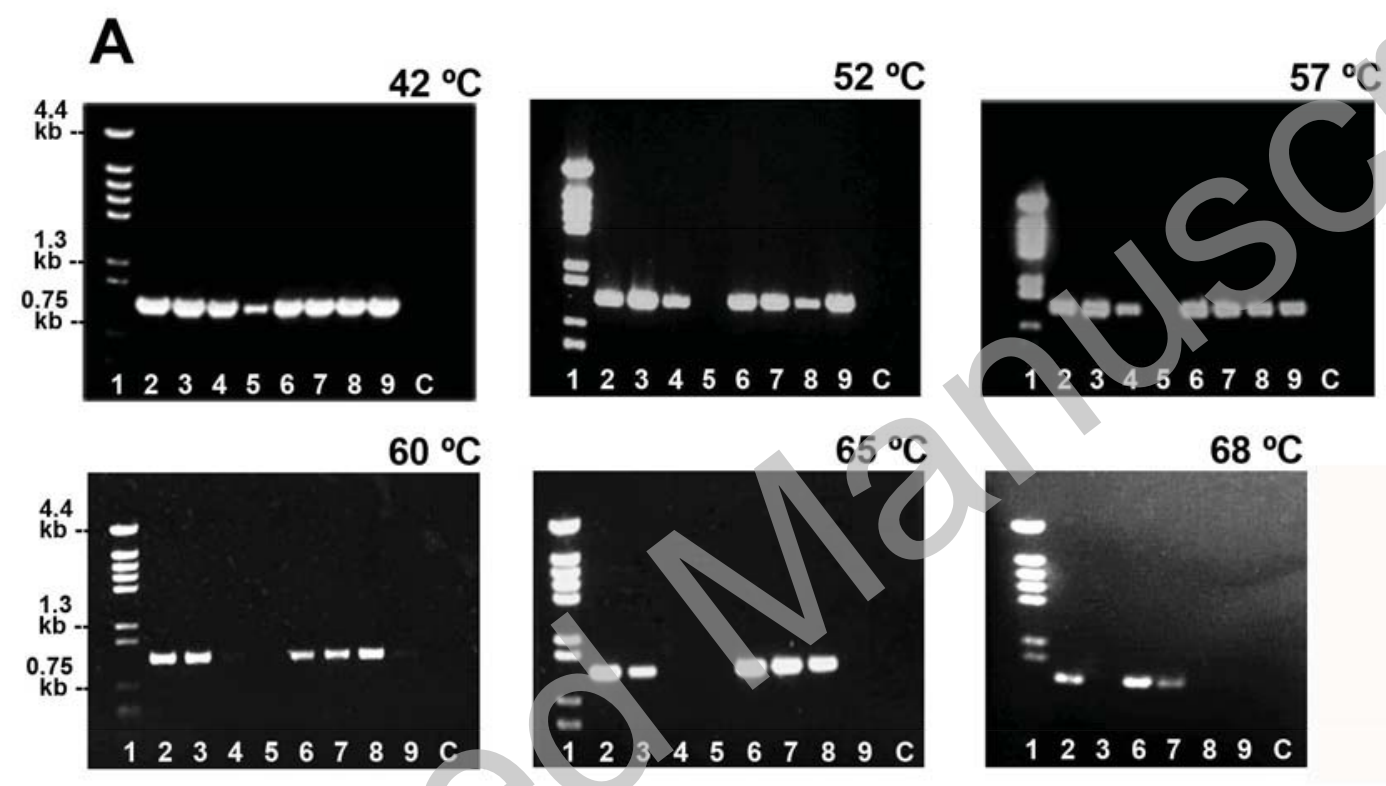

B

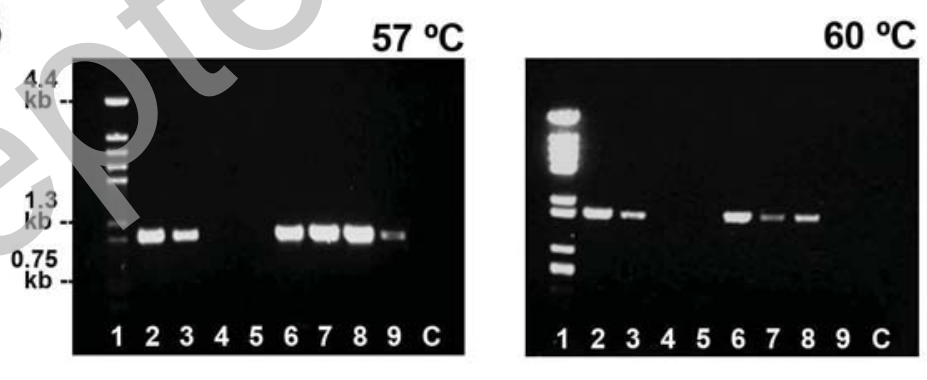

Licenced copy. Copying is not permitted, except with prior permission and as allowed by law. (C) 2011 The Authors Journal compilation (C) 2011 Portland Press Limited 


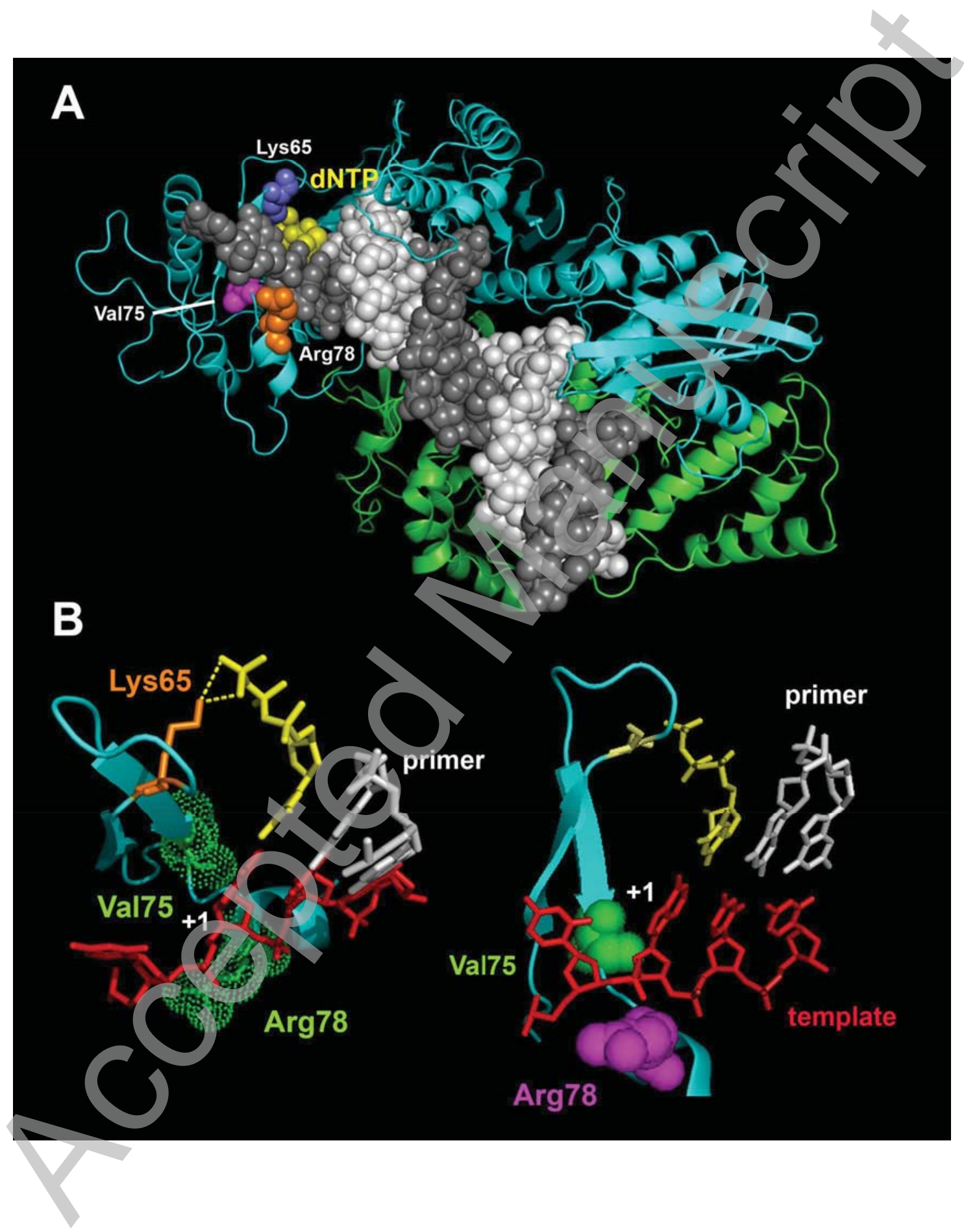

Licenced copy. Copying is not permitted, except with prior permission and as allowed by law. (c) 2011 The Authors Journal compilation (c) 2011 Portland Press Limited 